\title{
The Use of Racist Lexical Items and Irony in Richard Wright's Native Son
}

A Stylistic Study

\author{
Prepared by: \\ Dr Ahmad Hassan \\ Lecturer of English Language and Literature \\ Port Said University \\ Faculty of Arts \\ Department of English \\ 2015
}


هبلة كلية الآكابِ باهعة بهر رسعي

rA.

(20)

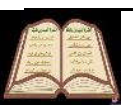

العكد الخاهس / بناير - ها·؟م 


\section{Abstract:}

Because language is the medium of communication and message conveying in literary works as is the case in other human activities that require the use of language whether verbally or nonverbally, it is very logical to study literary works linguistically to benefit from the findings of linguistics in reaching the best understanding of different genres of literature. Stylistics plays a major role in this domain since it is the area which combines the clashing teams of literary critics and linguists on the same ground. In this vein, this research aims at using Richard Wright's Native Son as the raw material for a linguistic stylistic analysis aiming at a deeper understanding of the motifs of both the author together with his protagonist. However, the analysis is limited to the use of some racist lexical items as employed by the writer starting from the title and including some of the most characteristic vocabulary features of the novel that obviously reflect the racist nature of the American society during the first decades of the twentieth century as thought by Wright.

\section{Introduction:}

The last few decades have witnessed a great revolution in the relationship between literary and linguistic studies where the two opposing teams have come to meet on the ground of stylistics which is considered the bridge between both teams. While literary products represent the seductive raw materials for linguistic analysis, stylistics offers the tools developed in linguistics to help deepen readers' understanding and enjoyment of a literary product. The researcher's interest in conducting this stylistic study is attributed to finding a common ground between linguists and literary critics and helping literature readers and students go deeper into literary works relying on the magic of understanding literary texts linguistically.

Additionally, the researcher was tempted by the great weight and fame of both Richard Wright and his masterpiece, Native Son. In fact, Richard Wright is one of America's most acclaimed writers who stands out as the father of the Black American writers as the advocate of the rights of the blacks in a dignified life as humans. In 1940, Wright published Native Son which achieved a great success together with much controversy due to its content as it was thought of as a cry

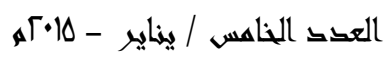


against the oppression that the blacks encountered in such a racist society as the American.

\section{Native Son:}

The novel handles the life and suffering of the American blacks as represented in the image of Bigger Thomas who faced the so many racist and inhuman acts of the white Americans against the blacks. Dramatically, he found himself in a white woman's bedroom and hence was able to get out of the critical situation only through unintentional killing of that white woman a thing that led Bigger to be put to trial sentenced to death and issuing a violent cry in the face of the American society due to the inhuman atmosphere and treatment he underwent reflecting America's fight against racism.

Lest of being chased by the scandal of being in Mary Dalton's; a white woman, Bigger happened to kill the white woman raising the question of the social responsibility of America's racism for sharing in the crime that suddenly made him as a victim of a rotten and racist environment with no mercy in the way it dealt with the blacks. That society must carry its part of the responsibility of creating a criminal out of a miserable poor black man struggling to live.

The opening of the novel is very shocking as it reflects the very miserable conditions of a black man who lives in a one-room flat that contains insects and animals as part of the image in that miserable place. Bigger Thomas is a black young man who was expecting a job to work as a chauffeur for the Dalton's; a white family. His mother urged him to accept the job because if he did not, they would be deprived of the social support offered by the local authorities.

He managed to get the job where his first task was to take Marry Dalton to college. However, the girl took him into another place where she met her boy friend instead of attending her classes. The girl and her boy friend's way of speaking to Bigger is full of so racist words that Bigger was left with the feeling of being ashamed of himself as black. When they, got home, Mary was so drunk that she needed someone take her to her bedroom and Bigger did that. Unfortunately, her mother, blind Mrs. Dalton, wanted to make sure that her daughter returned back and so she headed to her bedroom at the same time when Bigger was helping her and lest it should be known that a black man was

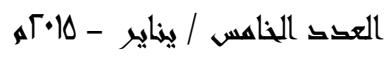


at the bedroom of a white girl, Bigger covered Mary's head with a pillow but unluckily, she died. He decided to burn her body to avoid being accused of murder and told Mrs. Dalton that the last person Mary saw was her boy friend Jan to make her think of Jan as the murderer of Mary. Eventually, he had to kill his girl friend Bessie who started to suspect him and his story was known and his secrets were revealed. He was put to trial and was sentenced to death.

Surprisingly enough, Jan assigned his friend Mr. Max; a communist lawyer to advocate him at the court and Bigger started to have confidence in Mr. Max and began to tell him very sophisticated details about his suffering as a member of the black community with very limited chances in life in a very racist society. Though Max did his best to save Bigger's neck, he failed and finally, Bigger is left alone in prison waiting for the execution of the capital punishment. Employing Max who is a Marxist lawyer as an advocate for Bigger's case shows part of Wright's personality as a leftist who joined the Marxist movement in America due to the bitterness he felt towards the racist spirit in America. As a black America, Wright has the same negative feeling as his protagonist as he wrote in introducing Native Son, "We black and they white. They got things and we ain't. They do things and we can't" (Wright 20). He has a feeling of inferiority and denied humanity and lack of belonging due to his race.

\section{Linguistic stylistic studies:}

Style may roughly be defined as the specific mechanism of using language and linguistic devices for serving specific literary goals while stylistics may be defined as the scientific study of those devices and traits that gather together to form a unique expression. There is a variety of definitions for both style and stylistics. For example, according to Leech and Short $(1981,13)$, stylistics is the linguistic study of style through which stylisticians explore the meanings and understand the linguistic features of the text. On the other hand, Short and Candlin $(1989,183)$ remark that stylistics is the linguistic approach to the study of literary texts. Widdowson $(1975,3)$ defines it as the study of literary discourse from a linguistic orientation. He also points out that it deals with both the literary and linguistic factors. Carter $(1988,161)$ refers to stylistics as a bridge discipline between linguistics and literature. Stylistics is then the bridge

$$
\text { العقد الخاهس / ينمايير - إ·مه }
$$


on which linguists and literary critics can meet as it includes the study of the devices in languages such as simplicity and complexity of structures and syntactical devices that are taken to produce expressive or literary style through specific linguistic devices or vocabulary items.

In fact, language is an important tool for understanding literary works and linguistic studies participate in anticipating the thread of actions and the intentions of the writer. Understanding the linguistic devices used in conveying meanings can, no doubt, enrich the experience of readers in their journey towards full understanding of the messages being sent and the concepts being addressed. Linguistic studies are meant to raise the entire awareness of the reader using scientific knowledge and devices as developed in linguistics.

\section{1. Linguistic analysis areas:}

This research focuses on the linguistic analysis of the phrasing of the title of the novel together with the most common lexical items as used in the novel and that reflect a special attitude on behalf of the writer towards certain concepts and issues such as the racist nature of the white Americans in the way they treat the blacks during the time of writing the novel. In fact, the novel contains a big number of dramatic dialogues and speech exchanges and comments that are considered a real wealth and temptation for useful linguistic analysis. However, few of them were subject to analysis in this research as a representative sample of the common trend of the novel.

Additionally, word classes such as general vocabulary and whether words are simple or complex, formal or colloquial, descriptive or evaluative will be handled. The question of how far the writer makes use of the different word class vocabulary and idiomatic phrases, the use of nouns and whether they are abstract or concrete, standard or slangy will also be covered.

\subsubsection{The title of the novel:}

Titles carry great weight in most literary works as they normally summarize and reflect the content and the conflict of the work they carry its name. However, some titles could be misleading and even shocking like the case in Native Son. The title of the novel is composed of two lexical items; the adjective native and

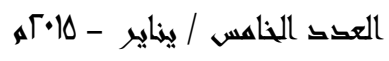


the noun son. The word native reflects an irony since it describes an American citizen who comes from the same environment in much the same way as the whites do. However, reading the novel shows that the way he is being dealt with never reflects a sense of belonging to that society. He is very much more like an outsider than a native and this is reflected in the way he behaved after being suddenly found at the bedroom of a white woman. Had he been a white man, would he have been in the same situation with the same fears? Of course, Bigger's violent reactions depicts a picture of an alienated and detached person rather than a native American citizen and the terror he felt condemns the givings of the American ideology though it does not let Bigger go completely innocent.

The second lexical item of the title is the noun son; a word which is supposed to represent the most precious member in the life of a mother if America were to be considered as a mother for all its sons regardless to their color, race or religion. Questions about the place in which Bigger and his family live, the life standard they live, the level of education they receive and many other dimensions cast thick doubts on the meaning of son. Again, the writer is very ironic in the choice of the word son. The title mocks the claimed values set by America to be sold to the world as mere illusions that never stand on solid grounds in reality. Therefore, it will be the first shock for the readers to discover that Bigger is neither a native nor a son.

\subsubsection{Narrative and racist lexical items:}

\subsubsection{First extract}

Dialogues are dramatically employed and they spread throughout the novel, with its three books, in a very big number and they are very much suggestive telling as a reflection of the general atmosphere of the American society at the time of writing the novel. Wright was able to employ them for serving the message he wanted to convey and the ideology he tended to represent. However, some illustrative samples from the novel are selected in the following few lines to offer a representative sample of the content that reflects the spirit of racism as provided by Wright. For example, Bigger's words in the following quotation tell a lot: 
He says, "All those white men in a group, guns in their hands, can't be wrong. I am guilty. I do not know of what, but I know that I am no good."

In this quote, the adjectives "white" and "guilty" are of great significance as they show the opposite positions ob both the whites who "can't be wrong" and the black man who is guilty though he knows nothing about his guilt. Bigger's words reflect a lack of self esteem and confidence and it represents a state of feeling inferior towards others society members of the American whites just because he is black. He is stating that the white people can never be wrong just because they are white. It is the concept of America at that time; a concept that white people can never be mistaken and hence, Bigger deduced that he must be wrong and he even goes further to say that he is not a good human being as he misses something as a black person. The most emotional part of his words is when he confesses that he must be guilty but he does know of what he is guilty and it is clear that he is the victim of the violence of the white who carry guns to impose the concept of power and confuse it with the idea of wronging the blacks for one reason or another. The nouns "group and gun" and the phrase "in their hands" all reflect the power of the white and their superiority in contrast the poor helpless blacks.

\subsubsection{Second extract}

In the following dialogue, Bigger is exchanging miserable words with Gus reflecting a feeling of tension despite the fact that they attempt to be funny. Some of the adjectives, nouns and phrases used are ironic as in:

"This is the President of the United States speaking," Bigger said. "Oh, yessuh, Mr. President," Gus said.

"I'm calling a cabinet meeting this afternoon at four o'clock and you, as Secretary of State, must be there."

"Well, now, Mr. President," Gus said, "l'm pretty busy. They raising sand over there in Germany and I got to send 'em a note. . . ."

The very next lines contain the adjectives "nigger and black" as commonly occurring on the tongues of the white reflecting the spirit of racism as a dominant concept in the American society:

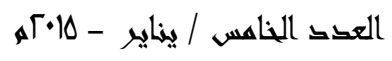


"What you going to take up at this cabinet meeting?" Gus asked.

"Well, you see, the niggers is raising sand all over the country," Bigger said, struggling to keep back his laughter. "We've got to do something with these black folks. ...."

"Oh, if it's about the niggers, l'll be right there, Mr. President," Gus said.

They hung up imaginary receivers and leaned against the wall and laughed. A street car rattled by. Bigger sighed and swore.

"Goddammit!"

"What's the matter?"

Although the two friends are mocking the way in which the whites speak, a feeling of bitterness controls the way they speak. They also used the words black and nigger showing how common it is for the whites to hurt the feelings of the blacks through using such painful words ignoring the feelings of their native brothers. Soon the situation is turned upon hearing a street car rattling it is obvious that the sound of the street car reminded them of the spirit of segregation that swept America at that time to the extent that the blacks were not allowed to ride the same cars with the whites.

\subsubsection{Third extract}

Another example of negative words that reflect the feeling of despair and helplessness is found in the following quote. When Bigger was talking again with Gus, he used the adjective "white" to reflect a state of powerlessness and his words are very much suggestive of how he feels towards the white people who allow no chance or hope for the nigger:

"They don't let us do nothing."

"Who?"

"The white folks."

In his comment, Gus also surrenders to that fact reminding Bigger that it is granted and there is no new news about that. Again, his reply reflects a state of hopelessness and full surrender to the situation they are fated to encounter:

"You talk like you just now finding that out," Gus said.

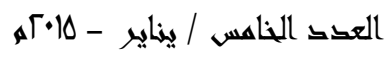


"Naw. But I just can't get used to it," Bigger said. "I swear to God I can't. I know I oughtn't think about it, but I can't help it. Every time I think about it I feel like somebody's poking a red-hot iron down my throat. Goddammit, look! We live here and they live there. We black and they white. They got things and we ain't. They do things and we can't. It's just like living in jail. Half the time I feel like I'm on the outside of the world peeping in through a knothole in the fence. ..."

"Aw, ain't no use feeling that way about it. It don't help none," Gus said. (1.229278)

It is clearly noticed that both of them fully understand that they have no place in the world of the white Americans. They are deprived of the simplest rights as humans and that the world they live in does not welcome their existence. Their words reflect a deep feeling of alienation and detachment from the society they are supposed to be its sons or in particular, native sons.

\subsubsection{Fourth extract}

The use of some words and phrases is employed to reflect a negative or positive state of mind or a specific psychology. The adjectives "awful and bitter" and the phrase "corner of the city" add to the feeling s of despair dominating the two black friends. The following extract reflects a state of pessimism as if Bigger were expecting the worst:

"You know one thing?" Big said.

"What?"

"Sometimes I feel like something awful's going to happen to me," Bigger spoke with a tinge of bitter pride in his voice.

"What you mean?" Gus asked, looking at him quickly. There was fear in Gus's eyes.

"I don't know. I just feel that way. Every time I get to thinking about me being black and they being white, me being here and they being there, I feel like something awful's going to happen to me...."

"Aw, for Chrissakes! There ain't nothing you can do about it. How come you want to worry yourself? You black and they make the laws. ..."

"Why they make us live in one corner of the city? Why don't they let us fly planes and run ships. ..."

Gus hunched Bigger with his elbow and mumbled good-naturedly, "Aw,_nigger,

$$
\text { العقد الخاهس / يناير - ها•مه. }
$$


quit thinking about it. You'll go nuts."

The plane was gone from the sky and the white plumes of floating smoke were thinly spread, vanishing. Because he was restless and had time on his hands, Bigger yawned again and hoisted his arms high above his head.

"Nothing ever happens," he complained.

"What you want to happen?"

"Anything," Bigger said with a wide sweep of his dingy palm, a sweep that included all the possible activities of the world.

Then their eyes were riveted; a slate-colored pigeon swooped down to the middle of the steel car tracks and began strutting to and fro with ruffled feathers, its fat neck bobbing with regal pride. A street car rumbled forward and the pigeon rose swiftly through the air on wings stretched so taut and sheer that Bigger could see the gold of the sun through their translucent tips. He tilted his head and watched the slate-colored bird flap and wheel out of sight over the edge of a high roof.

"Now, if I could only do that," Bigger said.

Gus laughed.

"Nigger, you nuts."

"I reckon we the only things in this city that can't go where we want to go and do what we want to do."

"Don't think about it," Gus said.

"I can't help it."

"That's why you feeling like something awful's going to happen to you," Gus said. "You think too much."

"What in hell can a man do?" Bigger asked, turning to Gus.

"Get drunk and sleep it off."

"I can't. l'm broke." (1.279-301)

In Bigger's words, a spirit of pessimism spreads throwing a feeling of fear of the future as he expects that something awful is going to happen to him. The reason for this feeling has to do with the color of his skin as a black person. This reflects the inhuman circumstances the blacks underwent during this period of the American history. Bigger's language becomes negative when he thinks of something that sweeps the world in which he lives; a world that gives nothing but despair, fear and helplessness. A feeling of frustration and oppression that is associated with negative adjectives such as "drunk", which denotes a trial to forget about the unfair world and "broke", which reflects 
poverty and helplessness always dominates both the words and style of Bigger's speech.

\section{Conclusion}

In fact, Native Son is an outstanding literary work that has always attracted both readers and critics to read, study and analyze. Starting from the title, there are many areas that are worth analysis and consideration as the title a cry in the face of the American society of the 1940s and the following decades; periods in which grew new trends and tendencies in the world in addition to different values and some writers, including Richard Wright, tried to deal with difference through reflecting these values in their works.

As part of that trend, Native Son handles the struggle of Bigger Thomas as a reflection of the themes as alienation, search for identity and violence. Wright himself wrote that he dreamed of a world of equality that allows fair chances for all people regardless to their color or race. He was all the time feeling that he is inferior to the white person in much the same way as is Bigger who is the protagonist of Native Son.

Stylistically speaking, many racist vocabulary items spread throughout the novel and the use of certain words reflects the ideology of the writer in relation to a variety of social and political issues. For example, Wright uses the word Negro and this refers to the worst position the black person has in life through his dealings and treatment with whites. It is known that Wright was taken by the Russian Revolution and this is represented in the Native Son through the character of Mr. Max, the communist lawyer who advocated the black murderer and sympathized with him. Max's final speech relates to the ideology of both Max and Wright as Marxists. The core of humanity bases itself upon respect of all groups of people. Max's speech at the trial scene almost had me convinced that the true murderers resided in all of those who push others towards crime and violence because of racial discrimination.

This means that a writer like Wright chooses the theme of his novel according to the environment in which he lives and employs the most effective linguistic devices that are able to clearly transmit his message. Wright wrote that Negroes become alienated from their own racial identity because they do not 
know who they are and if they know, they hate themselves. So, the works of Wright were revolving around the self-hatred related to the Negroes. In fact, Wright himself experienced the same feeling of self-hatred and he wrote that when he was encouraged by his white boss to fight with another black boy called Harrison.

In Native Son, Wright was determined to make his readers feel the reality of race relations by writing something "so hard and deep that they would have to face it without the consolation of tears." The protagonist of the novel, Bigger Thomas, hails from the lowest rung of society, and Wright does not infuse him with any of the romantic aspects or traits common to literary heroes. Rather, given the social conditions in which he must live, Bigger is what one might expect him to be-sullen, frightened, violent, hateful, and resentful.

In his essay "How Bigger Was Born," Wright explains that Bigger is a fusion of men he had himself known while growing up in the South.

Wright depended heavily on narrative techniques coming from his experiences and imagination as he himself faced several racial problems in his life and he was able to recall them in that cry of Native Son. In general, Wright was very successful in throwing a stone in the stand still water to motivate America towards changing itself; a change that could never be imagined if America of the 1940s thought of a black man in the Oval Office in the White House in Washington DC. 